\title{
Pendampingan RT Siaga Covid-19 Melalui Sosialisasi dan Edukasi Adaptasi Kebiasaan Baru
}

\author{
Tia Fajarani1*, Dewi Kurnia Sari², Vika Ridazaela ${ }^{3}$, Linda Suwarni ${ }^{4}$ iD \\ 1,2,3,4 Fakultas Ilmu Kesehatan, Universitas Muhammadiyah Pontianak, Indonesia \\ *Corresponding author: fajaranitia24@gmail.com
}

\begin{abstract}
Covid-19 menjadi pandemi global dengan tingkat peningkatan kasus yang semakin banyak. RT siaga Covid-19 dibentuk sebagai upaya dalam mencegah dan mengendalikan penyebaran virus. Namun, belum sepenuhnya RT Siaga Covid19 yang terbentuk berjalan sebagaimana fungsi keberadaannya. Tujuan pengabdian ini adalah untuk melakukan pendampingan RT Siaga Covid-19 melalui sosialisasi dan edukasi kebiasaaan baru. Jenis penelitian pengabdian kepada masyarakat. Populasi yang diambil Kelurahan Sungai Bangkong. Jenis pengumpulan datanya yaitu evaluasi. Metode kegiatan yang dilakukan melalui beberapa tahapan melalui konsolidasi, sosialisasi, dan edukasi, serta evaluasi kegiatan dan keberlanjutan kegiatan. Hasil kegiatan ini adalah terlaksananya kegiatan konsolidasi, sosialisasi protocol kesehatan dan edukasi adaptasi kebiasaan baru, serta edukasi perilaku hidup bersih dan sehat. Jadi, diperlukan komitmen konsisten yang dilaksanakan baik oleh pihak kelurahan maupun RT setempat agar RT Siaga Covid-19 dapat berjalan baik.
\end{abstract}

Keywords: Adaptasi Kebiasaan Baru, Protokol Kesehatan, Covid-19

\section{Abstract}

Results and Discussion Covid-19 is becoming a global pandemic with an increasing number of cases. The Covid-19 Alert RT was formed as an effort to prevent and control the spread of the virus. However, the Covid-19 Alert RT has not yet been fully formed as its function of existence. The purpose of this service is to provide assistance to the Covid-19 Alert RT through socialization and education of new habits in Sungai Bangkong Village. The type of community service research. The population was taken from Sungai Bangkong Village. The type of data collection is evaluation. The method of activities is carried out in several stages through consolidation, outreach, and education, as well as evaluation of activities and activity sustainability. The result of this activity is the implementation of consolidation activities. socialization of health protocols and education on adaptation of new habits, and education on hygiene and healthy living habits. The conclusion of this study requires a consistent commitment carried out by both the urban village and the local RT so that RT Siaga Covid-19 can run

Keywords: Adaptation to New Habits, Health Protocols, Covid-19

\section{Introduction}

Covid-19 adalah masalah Kesehatan global, tidak hanya menyerang Kesehatan namun juga sangat berdampak di segala bidang kehidupan manusia baik bidak social budaya, ekonomi dan bidang pendidikan (Wong et al., 2020). Covid-19 penyakit yang sangat menular yang disebabkan oleh SAR-CoV-2, yang menyebabkan sindrom pernapasan akut (Mishra et al., 2020; Remuzzi \& Remuzzi, 2020). Covid-19 menyerang hampir 100 Negara yang ada di Dunia, dengan penyebaran sangat cepat dan jumlah kematian yang fantastis (Sahu, 2020). Dengan penyebaran yang sangat cepat dan mengakibatkan kematian yang sangat besar dan kelumpuhan di segala bidang sehingga Covid-19 dijadikan sebagai pandemic. Adanya pandemic ini akan mengakibatakan perubahan, serta perubahan ini harus dilakukan oleh

$\begin{array}{lll}\text { History: } & & \text { Publisher: Undiksha Press } \\ \text { Received } & : 02 \text { August } 2020 & \text { Licensed: This work is licensed under } \\ \text { Revised } & : 09 \text { September } 2020 & \text { a Creative Commons Attribution 3.0 License } \\ \text { Accepted } & : 06 \text { October } 2020 & \text { CC OP OP } \\ \text { Published } & : \text { : } 30 \text { November } 2020 & \end{array}$


masyarakat (Panesar et al., 2020). Serta dikuti dengan kebijakan-kebijakan pemerintah dalam mencegah terjadinya penyebaran covid-19. Pemerintah sudah banyak melakukan upaya melalui berbagai macam strategi komunikasi kepada masyarakat dalam mencegah penularan Covid-19 di wilayah masing-masing.

Namun, belum secara komprehensif dan menerapkan sanksi jera bagi pelanggannya (Zahrotunnimah, 2020b) Kebijakan pemberlakukan lock down juga dilakukan sebagai antisipasi penyebaran Covid-19 (Zahrotunnimah, 2020a). Kota Pontianak merupakan ibukota Provinsi Kalimantan Barat yang termasuk dalam zona merah sebaran kasus Covid-19. Data dari gugus tugas percepatan penanganan Covid-19, kasus tertinggi pada Kota Pontianak (Pemerintah Kota Pontianak, 2020). Salah satu program pemberdayaan masyarakat dalam pencegahan Covid-19 di tingkat RT/RW Desa adalah melalui pembentukan RT/RW Siaga Covid-19. Pemberdayaan masyarakat yang dimaksud adalah melalui menggerakan seluruh komponen masyarakat dengan menggali potensi yang ada di masyarakat agar masyarakat dapat mampu berdaya dalam mencegah penularan Covid-19 (Kementrian Kesehatan RI, 2020). Kelurahan Sungai Bangkong merupakan salah satu kelurahan yang ada di Kecamatan Pontianak Kota, Kota Pontianak yang terdapat kasus positif terkonfirmasi Covid-19 terbanyak di Kota Pontianak, yaitu 39 kasus (Pemerintah Kota Pontianak, 2020). Beberapa RT yang ada di Kelurahan Sungai Bangkong sudah terbentuk RT Siaga Covid-19, namun beberapa juga belum. Masih minimnya pemahaman masyarakat tentang pencegahan Covid19 juga menjadi permasalahan, sehingga pola kehidupan adaptasi kebiasaan baru tidak terlaksana sebagaimana mestinya.

Berdasarkan situasi dan masalah tersebut maka tim pengabdi program studi kesehatan masyarakat Universitas Muhammadiyah Pontianak melakukan kegiatan pendampingan RT Siaga Covid-19 melalui sosialisasi dan edukasi adaptasi kebiasaan baru di Kelurahan Sungai Bangkong. Sosialisasi dan edukasi adalah salah satu cara yang bisa dilakukan untuk memberikan pengetahuan kepada mayarakat (Sari, 2020). Sosialisasi dan edukasi meningkatkan pengetahuan, sikap dan perilaku agar dapat menerapkan cara-cara hidup sehat dalam rangka menjaga, memelihara, dan meningkatkan Kesehatan (Aini \& Sriasih, 2020). Sosialisasi dan edukasi yang bisa dilakukan yang berkaitan dengan pencegahan Covid-19 adalah sosialisasi cuci tangan, penggunaan masker dan pentingnya Social Distancing (Candra et al., 2020; Syapitri et al., 2020).

Tujuan pengabdian ini adalah untuk melakukan pendampingan RT Siaga Covid-19 melalui sosialisasi dan edukasi kebiasaan baru. kegiatan ini adalah untuk meningkatkan pengetahuan masyarakat setempat tentang adaptasi kebiasaan baru dalam upaya menekan penyebaran Covid-19 di daerah tersebut. Dengan adanya kegiatan ini, akan membantu penyebaran covid-19 dan tentunya masyarakat lebih siap menghadapi adaptasi kehidupan baru.

\section{Materials and Methods}

Pelaksanaan dalam pengabdian kepada masyarakat ini dilakukan dengan beberapa tahapan, yaitu sebagai berikut: Pertama, Konsolidasi kegiatan pengabdian dengan pihak kelurahan. Konsolidasi dilakukan dengan pihak kelurahan dalam upaya menyinergikan program pengabdian yang dilaksanakan di wilayah kelurahan tersebut. Kegiatan ini merupakan tahap awal dalam kegiatan pengabdian agar mendapat dukungan sepenuhnya dan mendukung keberhasilan pelaksanaan kegiatan pengabdian yang dilakukan. Kedua, Sosialisasi protokol kesehatan dan adaptasi kebiasaan baru. Kegiatan ini dilakukan untuk membekali pengetahuan masyarakat setempat tentang protocol kesehatan dan adaptasi kebiasaan baru. Ketiga, Edukasi masyarakat tentang perilaku hidup bersih dan sehat. Edukasi ini dilakukan kepada masyarakat tentang perilaku hidup sehat agar dapat meningkatkan pengetahuan dan pemahaman masyarakat tentang pentingnya PHBS sebagai 
upaya preventif pencegahan penularan Covid-19 (Habibi et al., 2020; Irawan et al., 2020). Keempat, Evaluasi kegiatan dan rencana keberlanjutan. Kegiatan ini dilakukan untuk mengetahui kegiatan yang dilakukan dan rencana keberlanjutan program di masa mendat ang. Kegiatan ini dilaksanakan dari tanggal 30 Juli sampai dengan 01 September 2020. Kelurahan Sungai Bangkong menjadi lokasi pengabdian "Desa Siaga Covid-19". Kegiatan ini diawali dengan konsolidasi kegiatan pengabdian dengan Lurah secara langsung sebagai pihak Kelurahan Sungai Bangkong

\section{Results and Discussion}

\section{Konsolidasi Kegiatan Pengabdian dengan Pihak Kelurahan}

Kelurahan Sungai Bangkong menjadi lokasi pengabdian "Desa Siaga Covid-19". Kegiatan ini diawali dengan konsolidasi kegiatan pengabdian dengan Lurah secara langsung sebagai pihak Kelurahan Sungai Bangkong. Kegiatan konsolidasi dengan pihak kelurahan digabrakan pada gambar 1 berikut.

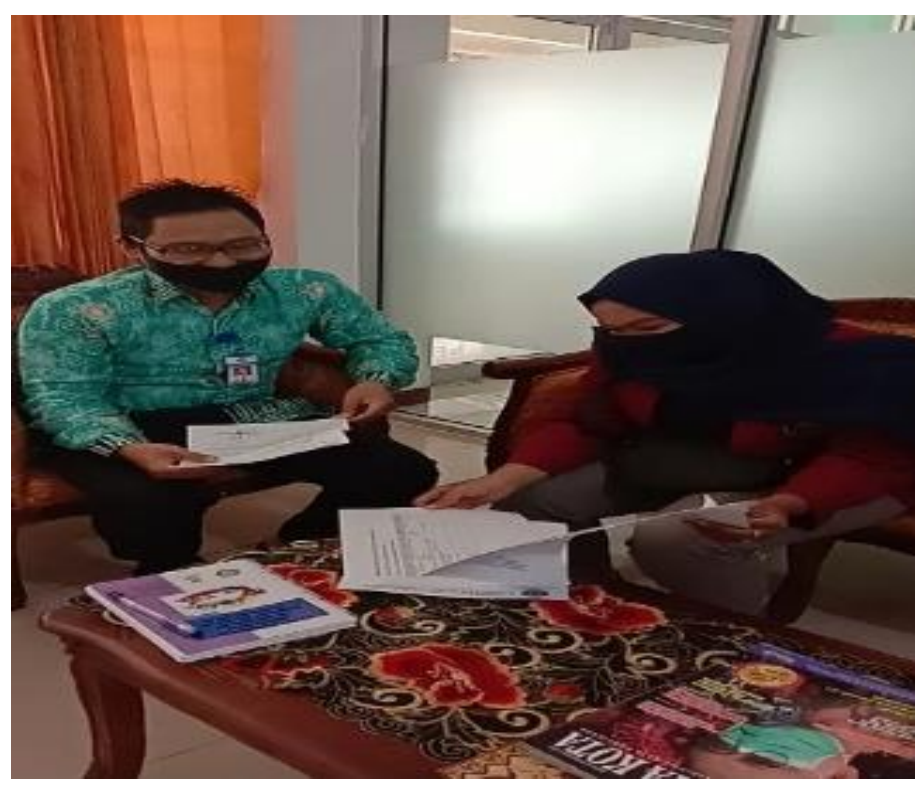

Gambar 1. Dokumentasi Kegiatan Konsolidasi Kegiatan Pengabdian dengan Pihak Kelurahan

Kegiatan konsolidasi ini dilakukan dalam upaya meminta izin dan penyamaan persepsi kegiatan pengabdian yang dilakukan. Hasil dari kegiatan ini adalah pihak kelurahan (Lurah Sungai Bangkong) menyambut baik kegiatan pengabdian yang akan dilakukan dan merasa terbantu akan adanya program ini pada masyarakat di wilayah kelurahan setempat. Dalam kegiatan pengabdian kepada masyarakat, konsolidasi merupakan tahapan yang penting dalam rangka penerimaan program yang akan dilakukan dan kelancaran serta keberlanjutan kegiatan yang dilakukan kedepannya (Hayat et al., 2013)

\section{Sosialisasi Protokol Kesehatan dan Adaptasi Kebiasaan Baru}

Pada tahap pelaksanaan adalah sosialisasi mengenai protokol kesehatan dan adaptasi kebiasaan baru. Kegiatan ini dilakukan di lapangan terbuka sambal berjemur matahari pada jam 09.00. Materi yang disampaikan dalam sosialisasi mencakup tentang Covid-19 seperti pengertian, gejala, cara penyebaran, dan cara memperlambat atau mencegah penyebaran Covid-19 seperti mencuci tangan sesering mungkin, hindari menyentuh wajah saat di luar 
rumah, hindari salaman atau bersentuhan dengan orang lain, menerapkan etika ketika batuk dan bersin, bersihkan barang-barang di sekitar kita ketika berpergian, cuci bahan makanan setelah dibeli dan selalu gunakan masker jika keluar rumah. Protokol kesehatan dan adaptasi kebiasaan baru juga ditekankan pada masyarakat yang mengikuti sosialisasi kegiatan ini, nampak pada Gambar 2 berikut.
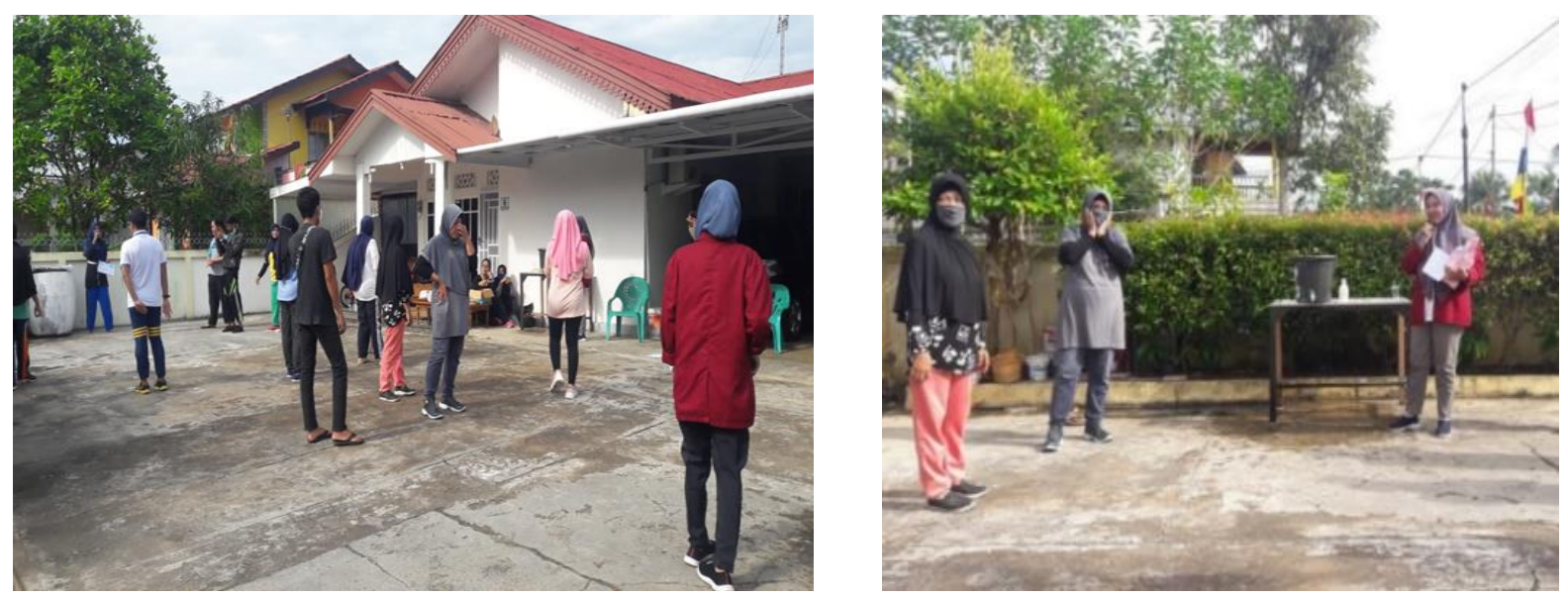

Gambar 2. Sosialisasi Protokol Kesehatan dan Adaptasi Kebiasaan Baru

Hasil kegiatan sosialisasi protocol kesehatan dan adaptasi kebiasaan baru ini memberikan pemahaman kepada masyarakat tentang Covid-19 dan protocol kesehatan serta adaptasi kebiasaan baru yang perlu dilakukan untuk mencegah penularan Covid-19. Sebelum dilakukan kegiatan sosialisasi ini banyak masyarakat yang salah memaknai dalam adaptasi kebiasaan baru atau yang biasa dikenal dengan new normal sebagai kehidupan yang biasa (normal) sama seperti sebelum adanya pandemic Covid-19. Setelah diberikan kegiatan sosialisasi ini terlihat peningkatan pengetahuan masyarakat tentang protocol kesehatan dan adaptasi kebiasaan baru. Hal ini terlihat saat tim pengabdi menanyakan satu per satu peserta sosialisasi tentang protocol kesehatan yang harus dilakukan dan kebiasaan yang di era new normal. Sejalan dengan pengabdian sebelumnya, kegiatan sosialisasi protocol kesehatan dapat meningkatkan pengetahuan dan kesadaran tentang Covid-19 (Habibi et al., 2020).

\section{Edukasi Masyarakat tentang Perilaku Hidup Bersih dan Sehat}

Edukasi tentang perilaku hidup bersih dan sehat melalui program cuci tangan yang baik dan benar. Langkah dalam mencuci tangan yang baik dan benar menurut WHO yaitu; membasuh tangan dengan air mengalir, gosok telapak tangan dengan sabun, sosok sela-sela jari, gosok punggung tangan, besihkan kuku-kuku tangan, gosok pergelangan tangan, dan bilas dengan air mengalir, keringkan tangan dengan handuk atau tissue. Kegiatan ini memiliki manfaat untuk melatih masyarakat dalam meningkatkan pengetahuan mengenai cara mencuci tangan yang benar menurut WHO serta sebagai upaya memutus mata rantai Covid-19. Sebelum adanya edukasi, banyak masyarakat yang tidak tahu cara mencuci tangan dengan langkah yang baik dan benar sesuai anjuran WHO, setelah adanya edukasi masyarakat mendapatkan pengetahuan dan mengerti cara mencuci tangan yang baik dan benar, nampak pada gambar 3 berikut. 

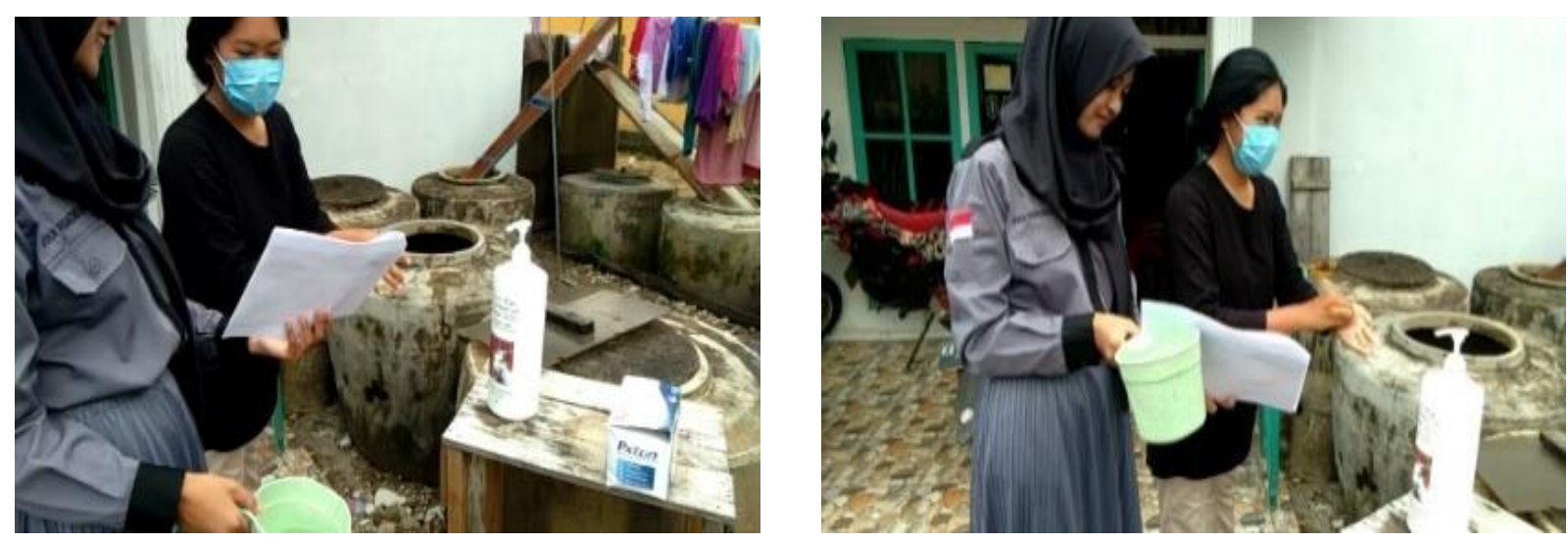

Gambar 3. Edukasi Masyarakat tentang Cuci Tangan Pakai Sabun

Edukasi tentang cuci tangan pakai sabun merupakan salah satu cara untuk mencegah penularan Covid-19 dan penyakit lainnya yang terkait dengan hand gygiene. Sejalan dengan kegiatan pengabdian yang dilakukan sebelumnya, edukasi cuci tangan pakai sabun signifikan meningkatkan pengetahuan tentang cara mencuci tangan dengan benar (Maulida et al., 2019; Nasir et al., 2020; Selviana \& Suwarni, 2018).

\section{Evaluasi Kegiatan dan Rencana Keberlanjutan}

Pada tahap evaluasi dari semua program yang telah dijalankan dilakukan pada pihak RT yang merupakan sasaran dari mitra pengabdian. Kegiatan yang telah dilakukan dinilai bermanfaat bagi masyarakat sekitar. Sebagai tindak lanjut dari kegiatan yang ada, maka ketua RT akan melanjutkan dan menerapkan program yang sudah disampaikan oleh tim pengabdi UM Pontianak. Selain itu, bukti tindak lanjut ini dibuktikan melalui surat pernyataan mengenai kesiapan melanjutkan program yang sudah ada dalam upaya mencegah penyebaran Covid-19 di wilayahnya.

Hasil kegiatan pengabdian yang dilakukan adalah terlaksananya konsolidasi kegiatan pengabdian dengan pihak kelurahan, sosialisasi protokol kesehatan dan adaptasi kebiasaan baru, edukasi masyarakat tentang perilaku hidup bersih dan sehat. Selain itu, pihak kelurahan dan RT akan menindaklanjuti terkait dengan program pengabdian yang sudah dilakukan melalui melanjutkan program yang ada dan mengontrol masyarakat sekitar di wilayah dapat menerapkan protokol kesehatan dan berperilaku hidup bersih dan sehat. Sosialisasi dan edukasi adalah salah satu cara yang bisa dilakukan untuk memberikan pengetahuan kepada mayarakat (Sari, 2020). Sosialisasi dan edukasi meningkatkan pengetahuan, sikap dan perilaku agar dapat menerapkan cara-cara hidup sehat dalam rangka menjaga, memelihara, dan meningkatkan Kesehatan (Aini \& Sriasih, 2020). Sosialisasi dan edukasi yang bisa dilakukan yang berkaitan dengan pencegahan Covid-19 adalah sosialisasi cuci tangan, penggunaan masker dan pentingnya Social Distancing (Candra et al., 2020; Syapitri et al., 2020).

Hasil penelitian ini didukung oleh hasil penelitian Soleh et al., (2020) menunjukkan Melalui sosialisasi dan edukasi, warga lebih memahami terkait dari pemahaman konsep, tanda atau gejala infeksi virus, tindakan pencegahan yang dilakukan jika terdapat anggota keluarga yang menunjukkan gejala Virus Corona (COVID- 19). Melalui brosur yang diberikan dan dipasang di bagian rumah warga juga dianggap efektif dalam pemahaman dan aplikasi. Selanjutnya pemberian masker kain sangat bermanfaat dalam mengurangi potensi penularan virus corona. Penelitian Maharani et al., (2020) menunjukkan adapun hasil dari pelaksanaan kegiatan ini adalah adanya pemahaman akan penyampaian materi tentang 
bagaimana mengatasi cemas dan pencegahan wabah Covid-19. Diskusi yang aktif serta antusias para peserta yang sangat baik saat menerima materi yang telah disajikan oleh tim pengabdi.

\section{Conclusion}

Hasil kegiatan pengabdian yang dilakukan adalah terlaksananya konsolidasi kegiatan pengabdian dengan pihak kelurahan, sosialisasi protokol kesehatan dan adaptasi kebiasaan baru, edukasi masyarakat tentang perilaku hidup bersih dan sehat. Selain itu, pihak kelurahan dan RT akan menindaklanjuti terkait dengan program pengabdian yang sudah dilakukan melalui melanjutkan program yang ada dan mengontrol masyarakat sekitar di wilayah dapat menerapkan protokol kesehatan dan berperilaku hidup bersih dan sehat.

\section{References}

Aini, \& Sriasih, M. (2020). Sosialisasi Perilaku Hidup Bersih dan Sehat (PHBS) di Tempat Kerja Sebagai Upaya Pencegahan Penularan Covid 19. Jurnal Pengabdian Magister Pendidikan IPA Original, 3(2), 171-174. https://doi.org/10.29303/jpmpi.v3i1.466

Candra, A. I., Santoso, S., Hendy, H., Ajiono, R., \& Nursandah, F. (2020). Upaya Pencegahan Penyebaran Virus Covid-19 Di Kelurahan Lirboyo Kota Kediri. Jurnal Ilmiah Pangabdhi, 6(2), 150-153. https://doi.org/10.21107/pangabdhi.v6i2.7395

Habibi, A., Normal, N., \& Baru, N. (2020). Normal Baru Pasca Covid-19 (Vol. 4).

Hayat, M., Salviana, V., Kds, R., Pengajar, S., Sosiologi, J., Ilmu, F., \& Politik, I. (2013). Pendampingan revitalisasi karang taruna. 10, 33-39.

Irawan, D., Triana, N., Suwarni, L., \& ... (2020). Edukasi Protokol Kesehatan dan Strategi Pemasaran Online Melalui Program Kemitraan Masyarakat di Era Pandemi Covid-19. JMM (Jurnal Masyarakat ..., 4(4), 7-9.

Maharani, J. F., Sulastri, N. M., Herlina, \& Rayani, D. (2020). Sosialisasi Pencegahan Covid 19 bagi Anak di PAUD Mutiara Islami Melalui Media Online. Jurnal Hasil Pengabdian \& Pemberdayaan Kepada Masyarakat, 1(1), 22-27. http://ojs.ikipmataram.ac.id/index.php/jpu

Maulida, D. Y., Ernyasih, \& Andriyani. (2019). Edukasi dan Pendampingan Praktek Cuci Tangan Pakai Sabun ( CTPS ) Pada Anak-Anak DI TK Al-Khoirot. Prosiding Seminar Nasional Pengabdian Masyarakat LPPM UMJ, September 2019, 1-4.

Mishra, D. L., Gupta, D. T., \& Shree, D. A. (2020). Online Teaching-Learning in Higher Education during Lockdown Period of COVID-19 Pandemic. International Journal of Educational Research Open, 100012. https://doi.org/10.1016/j.ijedro.2020.100012

Nasir, N. M., Farah, W., Desilfa, R., Khaerudin, D., Safira, Y., Intan, V. A., Maulana, A. S., \& Warahmah, M. (2020). Edukasi Perilaku Cuci Tangan Pakai Sabun Pada Siswa SD Di Tangerang Selatan. Jurnal Pengabdian Dan Pemberdayaan Kesehatan Masyarakat, 1(1), 45-49.

Panesar, K., Dodson, T., Lynch, J., Bryson-Cahn, C., Chew, L., \& Dillon, J. (2020). Evolution of COVID-19 Guidelines for University of Washington Oral and Maxillofacial Surgery Patient Care. Journal of Oral and Maxillofacial Surgery, 78(7), 1136-1146. https://doi.org/10.1016/j.joms.2020.04.034

Remuzzi, A., \& Remuzzi, G. (2020). COVID-19 and Italy: what next? The Lancet, 395(10231), 1225-1228. https://doi.org/10.1016/S0140-6736(20)30627-9 
Sahu, P. (2020). Closure of Universities Due to Coronavirus Disease 2019 (COVID-19): Impact on Education and Mental Health of Students and Academic Staff. Cureus, 2019(4), 4-9. https://doi.org/10.7759/cureus.7541

Sari, M. K. (2020). Sosialisasi tentang Pencegahan Covid-19 di Kalangan Siswa Sekolah Dasar di SD Minggiran 2 Kecamatan Papar Kabupaten Kediri. Jurnal Karya Abdi, 4(1), 80-83. https://online-journal.unja.ac.id/JKAM/article/view/9821

Selviana, S., \& Suwarni, L. (2018). Promosi Kesehatan Melalui Media Film Dalam Upaya Meningkatkan Perilaku Hidup Bersih dan Sehat Anak Sekolah Dasar Wilayah Pesisir $\begin{array}{llll}\text { Kepulauan. Jurnal } & \text { Abdimas }\end{array}$ https://doi.org/10.24903/jam.v2i2.376

Soleh, A., Suwarni, S., \& Yasirudin, N. T. (2020). Covid-19 Dan Upaya Pencegahan Penyebaran Di Rt 15 Rw 03 Kelurahan Rawa Makmur Permai Kecamatan Muara Bangkahulu Kota Bengkulu. Jurnal Pengabdian Masyarakat Bumi Raflesia, 3(2), 379-384. https://doi.org/10.36085/jpmbr.v3i2.899

Syapitri, H., Siregar, L. M., \& Saragih, F. L. (2020). Pencegahan Penularan Covid-19 Melalui Sosialisasi Dan Pembagian Masker Di Pasar Pringgan Medan. Jurnal Kreativitas Pengabdian Kepada Masyarakat (PKM), 3(2), 422-429.

Wong, G. L. H., Wong, V. W. S., Thompson, A., Jia, J., Hou, J., Lesmana, C. R. A., Susilo, A., Tanaka, Y., Chan, W. K., Gane, E., Ong-Go, A. K., Lim, S. G., Ahn, S. H., Yu, M. L., Piratvisuth, T., \& Chan, H. L. Y. (2020). Management of patients with liver derangement during the COVID-19 pandemic: an Asia-Pacific position statement. The Lancet Gastroenterology and Hepatology, 5(8), 776-787. https://doi.org/10.1016/S2468-1253(20)30190-4

Zahrotunnimah. (2020a). Konsep Tafakkur Dalam Alquran Dalam Menyikapi Coronavirus Covid-19. SALAM: Jurnal Sosial Dan Budaya Syar-I, 7(3), 247-260. https://doi.org/10.15408/sjsbs.v7i3.15048

Zahrotunnimah, Z. (2020b). Langkah Taktis Pemerintah Daerah Dalam Pencegahan Penyebaran Virus Corona Covid-19 di Indonesia. SALAM: Jurnal Sosial Dan Budaya Syar-I, 7(3). https://doi.org/10.15408/sjsbs.v7i3.15103 